\title{
Comparison of Bypassing Agents in Bleeding Reduction in Treatment of Bleeding Episodes in Patients With Haemophilia and Inhibitors
}

\author{
Mina Golestani ${ }^{1,} ;$ Peyman Eshghi ${ }^{2} ;$ Hamid Reza Rasekh ${ }^{1} ;$ Abdol Majid Cheraghali ${ }^{3} ;$ Jamshid \\ Salamzadeh ${ }^{1}$; Ali Imani ${ }^{4}$ \\ ${ }^{1}$ School of Pharmacy, Shahid Beheshti University of Medical Sciences, Tehran, IR Iran \\ ${ }_{2}^{2}$ Pediatric Congenital Hematologic Disorders Research Center, Shahid Beheshti University of Medical Sciences, Tehran, IR Iran \\ ${ }^{3}$ School of Pharmacy, Baqiyatallah University of Medical Sciences, Tehran, IR Iran \\ 4 Iranian Center of Excellence in Health Management, Faculty of Management and Medical Informatics, Tabriz University of Medical Sciences, Tabriz, IR Iran \\ ${ }^{*}$ Corresponding Author: Mina Golestani, School of Pharmacy, Shahid Beheshti University of Medical Sciences, Tehran, IR Iran. Tel: +98-9125160488, Fax: +98-4133351048, E-mail: mgoles- \\ tani8958@gmail.com
}

Received: October 13, 2014; Revised: November 16, 2014; Accepted: November 17, 2014

\begin{abstract}
Context: Mild-to-moderate bleeding disorders in haemophilia are primarily treated via recombinant activated factor VII a (rFVIIa) or activated prothrombin complex concentrate (aPCC). However, the efficacy of each bypassing agents may vary and none of them is universally effective.

Evidence Acquisition: After reviewing the databases of PubMed, Scopus, MD Consult, Ovid, Trip database, Google Scholar, ProQuest and the Cochrane Library, finally, 17 papers published from 2000 to 2013 were extracted. We used as a random effect model in meta-analysis. Comprehensive meta-analysis (CMA) software was used for calculating and estimating the mean of bleeding reduction and performing meta-analysis.

Results: The mean of bleeding reduction in aPCC and rFVIIa were 71.2\% with CI 95\% (lower limit 86.8\% and upper limit 82\%) and 72.3\% with CI 95\% (lower limit 57.6\% and upper limit 83.4\%), respectively.

Conclusions: Although differences between the two products were very close to each other, they reported similar effects on joint bleeds Further clinical studies should be performed by incorporating a standardized measurement in comparative efficacy of aPCC and rFVIIa.

Keywords: Haemophilia; Meta-Analysis; Bleeding
\end{abstract}

\section{Context}

Management of treatment for patients with haemophilia A or B with factor VIII/IX inhibitors is primarily conducted by administration of either recombinant activated factor VII (rFVIIa) or plasma-derived activated prothrombin complex concentrate (aPCC) (1). Patients with haemophilia and inhibitors have an increased risk of developing joint damage, leading to reducing the quality of life, compared to patients without inhibitors (2). Haemophilia is not only treated with a wide variety of products, but its dose is also managed from the lowest to the maximum in similar cases (3). Prevention from joint bleed or interrupting target joint bleeding in patients without inhibitors is primarily conducted by the use of regular prophylactic doses of factor concentrates (4). Haemophilia treatment is mainly aimed at decreasing the joint bleed and arresting the progression of joint destruction, to increase the quality of life (5). The efficacy of any bypassing agent varies, as seen in many studies; factor eight inhibitor bypassing activity (FEIBA) is effective in $80-100 \%$ of cases (6). On the other hand, other studies have reported more than $90 \%$ success, which was close to $60 \%$ when rFVIIa was used in treating acute bleeds (7). However, these studies demonstrate that bypassing agents are effective in most cases, although none of them is universally effective (6). To sum up the studies by now and by adding the knowledge of the bleeding reduction via bypassing agents in the treatment of joint bleed in patients with haemophilia and inhibitors, a systematic review of data was carried out by using a meta-analytic approach.

\section{Evidence Acquisition}

A systematic search was conducted among the published literature on studies that have compared the bleeding reduction of bypassing agents in treatment of haemophilia in patients with inhibitors. For including all the relevant studies, an initial search was conducted in PubMed, Scopus, MD Consult, Ovid, Trip database, Google Scholar, ProQuest and the Cochrane Library to identify papers published from 2000 to 2013. The search terms included a combination of the following: ['hemophilia' A or 'haemophilia'] and ['inhibitor' or 'antibody'] or ['recombinant factor' or 'rFVIIa'] or ['prothrombin complex concentrate' or 'aPCC'], bleed, bleeds, bleeding, haemorrhage, bypassing agent, bleeding reduction, bleeding stopped, bleeding controlled, cessation of bleeding,

Copyright (C) 2014, Iranian Red Crescent Medical Journal. This is an open-access article distributed under the terms of the Creative Commons Attribution-NonCommercial 4.0 International License (http://creativecommons.org/licenses/by-nc/4.0/) which permits copy and redistribute the material just in noncommercial usages, provided the original work is properly cited. 
bleeding resolved, bleeding treated and haemostasis. Each database had its own characteristics which led to varying search strategies and a specific algorithm. All the searches were in English. Although in two relevant studies authors have received grants, in many other studies authors had no conflict of interests. For the initial screening, papers were excluded if they were irrelevant to comparing bleeding reduction with bypassing agents based on the titles and abstracts and full texts were obtained and reviewed if the relevancy was not sufficiently determined by title and abstract. If aPCC and rFVIIa were used for prophylaxis or immune tolerance induction, treating bleeds in surgical patients or non-hemophiliac patients, those studies were excluded. The standardized extraction table contains information such as study design, year of publication, geographical region, drug type, dosage, number of joint bleeds evaluated, and the amount of bleeding reduction. If the information was not found in abstract or full text, the corresponding author was contacted to obtain the required information; if they were not available, they were excluded. After searching the databases, manual search through some valid journals in this field was performed. To increase the confidence of identification and analysis of the articles, the reference lists of the selected articles were also searched. We used two reviewers for evaluating all the papers. Kappa

\begin{tabular}{|c|c|c|c|c|c|c|c|c|}
\hline \multirow{2}{*}{$\begin{array}{l}\text { Author, Country, } \\
\text { year }\end{array}$} & \multirow[t]{2}{*}{ Study Design } & \multicolumn{2}{|c|}{ Sample Size } & \multirow{2}{*}{$\begin{array}{c}\text { aPCC Data } \\
\text { Source } \\
\end{array}$} & \multicolumn{2}{|c|}{ Average of Dosage } & \multicolumn{2}{|c|}{ Bleeding Reduction } \\
\hline & & aPCC & rFVIIa & & aPCC & rFVIIa & aPCC & rFVIIa \\
\hline $\begin{array}{l}\text { Dimichele D, USA, } \\
2006 \text { (8) }\end{array}$ & $\begin{array}{l}\text { Retrospective } \\
\text { post-licensure } \\
\text { survey }\end{array}$ & $\begin{array}{l}163 \text { joint } \\
\text { bleeds }\end{array}$ & - & $\begin{array}{l}\text { Retrospective } \\
\text { post-licensure } \\
\text { survey }\end{array}$ & $72 \mathrm{U} / \mathrm{kg}$ & - & $\begin{array}{l}67 \% \text { Cessation of } \\
\text { bleeding }\end{array}$ & - \\
\hline $\begin{array}{l}\text { G. Young, USA, } \\
2012(9)\end{array}$ & $\begin{array}{c}\text { Retrospectively } \\
\text { review }\end{array}$ & - & 129 inhibitor & literature & - & $630 \mu \mathrm{g} / \mathrm{kg}$ & - & 90\% bleeding stopped \\
\hline $\begin{array}{l}\text { Astermark, } 2007 \\
\text { (FENOC)(10) }\end{array}$ & Randomized trial & 48 bleeds & 48 bleeds & NA & $85 \mathrm{IU} / \mathrm{kg}$ & $2.205 \mathrm{mic} / \mathrm{kg}$ & $\begin{array}{l}77.8 \% \text { efficacy } \\
\text { rate }\end{array}$ & $75.6 \%$ efficacy rate \\
\hline $\begin{array}{l}\text { Knight, UK, } 2003 \\
\text { (11) }\end{array}$ & Cost minimization & NA & NA & literature & $180 \mathrm{U} / \mathrm{kg}$ & $207 \mathrm{mic} / \mathrm{kg}$ & $88 \%$ efficacy rate & 92\% efficacy rate \\
\hline $\begin{array}{l}\text { Odeyemi et al. UK, } \\
2002(12)\end{array}$ & CMA & NA & NA & $\begin{array}{l}\text { Literature and } \\
\text { panelists evalu- } \\
\text { ation }\end{array}$ & $\begin{array}{c}75^{*} 3225 \\
\mathrm{U} / \mathrm{kg}\end{array}$ & $90 * 2.3207 \mathrm{mic} / \mathrm{kg}$ & $\begin{array}{l}79 \% \text { of bleeds } \\
\text { treated }\end{array}$ & $92 \%$ of bleeds treated \\
\hline $\begin{array}{l}\text { Chung et al. USA, } \\
2004 \text { (13) }\end{array}$ & Decision tree & NA & NA & literature & $75 \mathrm{U} / \mathrm{kg}$ & $90 \mathrm{mic} / \mathrm{kg}$ & 78\% efficacy rate & 87.5\% efficacy rate \\
\hline $\begin{array}{l}\text { Putnam, USA, } 2005 \\
\text { (14) }\end{array}$ & Decision tree & NA & NA & $\begin{array}{l}\text { Literature and } \\
\text { panelists evalu- } \\
\text { ation }\end{array}$ & $75 \mathrm{U} / \mathrm{kg}$ & $270 \mathrm{mic} / \mathrm{kg}$ & $75 \%$ efficacy rate & $90 \%$ efficacy rate \\
\hline $\begin{array}{l}\text { Dundar et al. Tur- } \\
\text { key, } 2005 \text { (15) }\end{array}$ & Decision tree & $\begin{array}{l}9 \text { joint } \\
\text { bleeds }\end{array}$ & 28 joint bleeds & $\begin{array}{l}\text { Literature and } \\
\text { panelists evalu- } \\
\text { ation }\end{array}$ & $166.8 \mathrm{U} / \mathrm{kg}$ & $204 \mathrm{mic} / \mathrm{kg}$ & $\begin{array}{l}79 \% \text { of bleeds } \\
\text { treated }\end{array}$ & $89.3 \%$ of bleeds treated \\
\hline $\begin{array}{l}\text { Joshi et al. USA, } \\
2006(16)\end{array}$ & Decision analytic & NA & NA & literature & $180 \mathrm{U} / \mathrm{kg}$ & $207 \mathrm{mic} / \mathrm{kg}$ & 78\% efficacy rate & $92 \%$ efficacy rate \\
\hline $\begin{array}{l}\text { Ozelo et al. Brazil, } \\
2007 \text { (17) }\end{array}$ & Decision tree & 67 bleeds & 36 bleeds & $\begin{array}{l}\text { Observational } \\
\text { and retrospec- } \\
\text { tive study }\end{array}$ & $\begin{array}{c}260.2 \mathrm{U} / \\
\mathrm{kg}\end{array}$ & $189.9 \mathrm{mic} / \mathrm{kg}$ & $\begin{array}{l}56.7 \% \text { efficacy } \\
\text { rate }\end{array}$ & $100 \%$ efficacy rate \\
\hline $\begin{array}{l}\text { You et al. South } \\
\text { Korea, } 2009(18)\end{array}$ & Decision tree & 25 bleeds & 31 bleeds & $\begin{array}{l}\text { Observational } \\
\text { and retrospec- } \\
\text { tive study }\end{array}$ & $168 \mathrm{U} / \mathrm{kg}$ & $136 \mathrm{mic} / \mathrm{kg}$ & $\begin{array}{l}63.6 \% \text { efficacy } \\
\text { rate }\end{array}$ & 87.1\% efficacy rate \\
\hline $\begin{array}{l}\text { Kavakli et al. Tur- } \\
\text { key, } 2006 \text { (19) }\end{array}$ & Randomized trial & - & $\begin{array}{l}40 \text { bleeds } 90 \\
\mathrm{mic} / \mathrm{kg} \text { and } \\
270 \mathrm{mic} / \mathrm{kg}\end{array}$ & NA & - & $\begin{array}{c}90 \mathrm{mic} / \mathrm{kg} 270 \\
\mathrm{mic} / \mathrm{kg}\end{array}$ & & $\begin{array}{l}\text { With } 90 \mathrm{mic} / \mathrm{kg} 70 \% \\
\text { bleeds with } 270 \mathrm{mic} / \mathrm{kg} \\
65 \% \text { bleeds resolved }\end{array}$ \\
\hline $\begin{array}{l}\text { Santagostino, Italy, } \\
2006(20)\end{array}$ & Randomized trial & - & 32 joint bleed & NA & - & $90 \mathrm{mic} / \mathrm{kg}$ & - & $31 \%$ efficacy rate \\
\hline $\begin{array}{l}\text { Holme et al. Eu- } \\
\text { rope, } 2009(21)\end{array}$ & Prospective & $\begin{array}{l}214 \text { joint } \\
\text { bleeds }\end{array}$ & NA & $\begin{array}{c}\text { Prospective } \\
\text { study }\end{array}$ & $75 \mathrm{IU} / \mathrm{kg}$ & $90 \mathrm{mic} / \mathrm{kg}$ & $85 \%$ efficacy rate & $86 \%$ efficacy rate \\
\hline $\begin{array}{l}\text { Smejkal et al. Eu- } \\
\text { rope, } 2009 \text { (22) }\end{array}$ & Retrospective & $\begin{array}{l}45 \text { joint } \\
\text { bleeds }\end{array}$ & - & NA & $60 \mathrm{IU} / \mathrm{kg}$ & - & $95 \%$ effective & - \\
\hline $\begin{array}{l}\text { Mauser-Bun- } \\
\text { schoten, 2002, } \\
\text { Netherlands (23) }\end{array}$ & Prospective & - & 43 bleeds & $\begin{array}{l}\text { Prospective } \\
\text { study }\end{array}$ & - & $90 \mathrm{mic} / \mathrm{kg}$ & - & $80 \%$ effective \\
\hline $\begin{array}{l}\text { G. Young, USA, } \\
2008(24)\end{array}$ & $\begin{array}{l}\text { Randomize clini- } \\
\text { cal trial }\end{array}$ & $\begin{array}{l}22 \text { bleed } \\
\text { events }\end{array}$ & $\begin{array}{c}24 \text { bleed } \\
\text { events } 22 \\
\text { bleed events }\end{array}$ & Trial study & $75 \mathrm{IU} / \mathrm{kg}$ & $\begin{array}{c}270 \mathrm{mic} / \mathrm{kg} 90 \\
\mathrm{mic} / \mathrm{kg}\end{array}$ & $27.3 \%$ & $\begin{array}{l}37.5 \% \text { with } 270 \mathrm{mic} / \mathrm{kg} \\
54.5 \% \text { with } 90 \mathrm{mic} / \mathrm{kg}\end{array}$ \\
\hline
\end{tabular}
comparative. 
coefficient between the reviewers was calculated via SPSS as $16(\mathrm{~K}=0.82)$. To assess the quality of the selected articles, reviewers evaluated the articles according to the checklist of Strengthening the Reporting of Observational Studies in Epidemiology (STROBE) and Consolidated Standards of Reporting Trials (CONSORT).

\subsection{Statistical Analysis}

For excluding some studies regarding the weaknesses of methodological and administration point of view, from 17 entered articles, 11 were entered into metaanalysis. Due to lack of information on sample size, six studies were excluded. In this study, considering the Cochran's Q test result indicating heterogeneity among different study results, a model with random effect in meta-analysis was used. Comprehensive meta-analysis (CMA) software was used for calculating and estimating the mean of bleeding reduction and performing metaanalysis. Forest plots were used for reporting the results, as the size of each square represents the sample size and the lines drawn on each side of the square represent $95 \%$ confidence interval (CI) for the mean of bleeding reduction in each study.

\section{Results}

The search identified 553 studies in PubMed, 24 in Trip, 11 in MD consult, 170 in ProQuest, and 29 studies were identified manually and in gray literatures of some valid journals. Finally, 17 studies were chosen out of 787 potentially relevant ones. The flowchart of the study selection process is shown in Figure 1. The details of the studies included in the review are shown in Table 1 . The results of this study showed that the mean of bleeding reduction in aPCC and rFVIIa were respectively 71.2\% with CI 95\% (lower limit $86.8 \%$ and upper limit $82 \%$ ) and $72.3 \%$ with CI $95 \%$ (lower limit 57.6\% and upper limit 83.4\%). Figure 2 indicates the mean of efficacy of aPCC in bleeding reduction with 95\% CI of total studies. In Figure 3, the funnel plot indicates the mean of aPCC efficacy in bleeding reduction. Figure 4 indicates the mean of rFVIIa efficacy in bleeding reduction based on the randomized model, which was estimated at $72.3 \%$ with CI $95 \%$ (lower limit $57.6 \%$ and upper limit 83.4\%) (Q value $=68.1, \mathrm{df}=9, \mathrm{P}$ value $<0.001, \mathrm{I}^{2}$ $=80.5)$. In Figure 5, the funnel plot indicates the mean of rFVIIa efficacy in bleeding reduction.

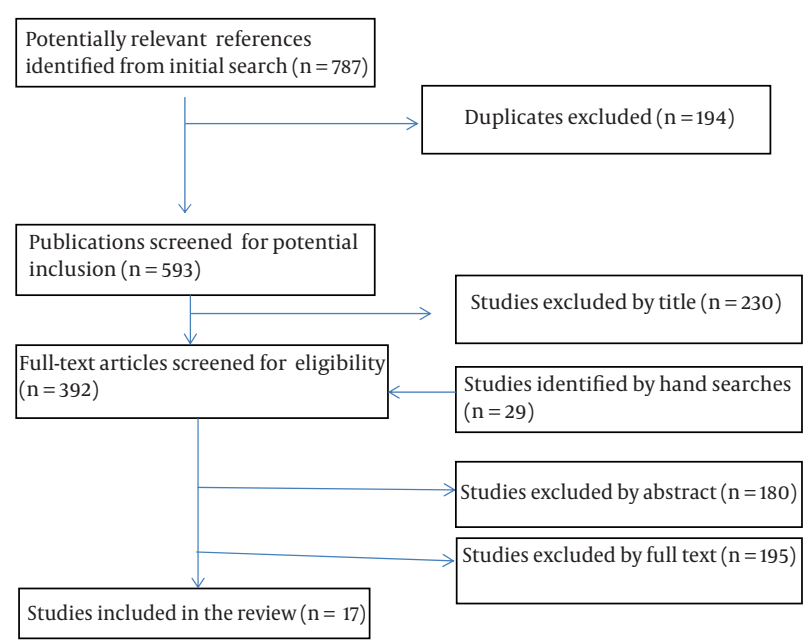

Figure 1. Flow Chart of Systematic Search

Figure 2. Mean of aPCC Efficacy in Bleeding Reduction Based on Randomized Model

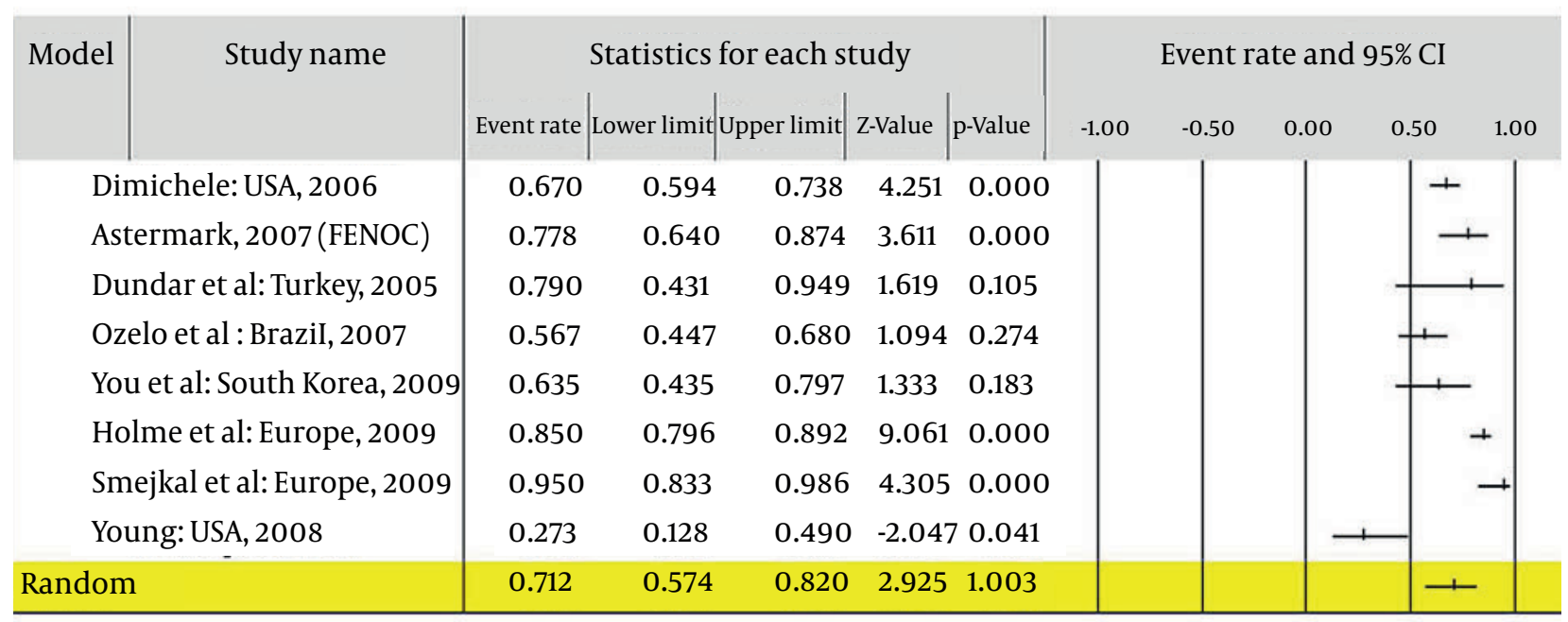

It was estimated 71.2\% with CI 95\% (lower limit 86.8\% and upper limit 82\%); $\mathrm{Q}$ value $=53.4 ; \mathrm{df}=7$; $\mathrm{P}$ value $<0.001, \mathrm{I}^{2}=86.6$ 
Treatment of patients with haemophilia is challenging and highly costing for effective management (25). Because of the important role of bypassing agents in the treatment of patients with haemophilia, an important point is understanding their relative effectiveness in reducing the rate of bleeding (26). The mean of bleeding reduction in aPCC and rFVIIa were respectively $71.2 \%$ and $72.3 \%$. The FEIBA NovoSeven comparative (FENOC) study compared $75 \mathrm{IU} \mathrm{kg}^{-1}$ of aPCC with $2 \times 90 \mu \mathrm{g} \mathrm{kg}^{-1}$ of rFVIIa. The results showed that there was no significant difference between the two treatments at no time. The bypassing agents showed similar efficacy on joint bleeds (10). This study indicated that with $95 \% \mathrm{CI}$, these products exhibited similar effects on joint bleeds. Given that the effectiveness of bypass in agents differs in several studies, the results of this study showed that these differences are very close to each other. Zhou et al. (26) compared the pooled efficacy of bypassing agents via classic meta-analysis approach. About 2400 joint bleeds from 19 studies were analyzed, which suggested that there was no statistically significant difference between aPCC and rFVIIa in efficacy when it is used for treating joint bleeds. The efficacy of bypassing agents to control bleeding episodes has been documented in the literature with success rates ranged 80-90\%(27-30). There is variability in response(31). Excluding the FENOC trial data (10), the bypassing agents data from cohort studies suggest that bleeds would be more quickly resolved if treated with rFVIIa rather than with aPCC; it is more than $90 \%$ for rFVIIa at nine hours and between $36 \%$ and $52 \%$ for aPCC (32). This is also similar to the finding of Treur et al. (33) meta-analysis, which calculated that $75 \%$ of bleeds treated with rFVIIa would be resolved by 12 hours compared with only $36 \%$ of bleeds treated with aPCC.

\subsection{Study Limitations}

This study, like many other ones, is influenced by publication bias. Studies without significant differences between comparisons have not been published much (34). Sometimes, heterogeneity could not be evaluated from the available data. Early treatment of bleeding episodes is

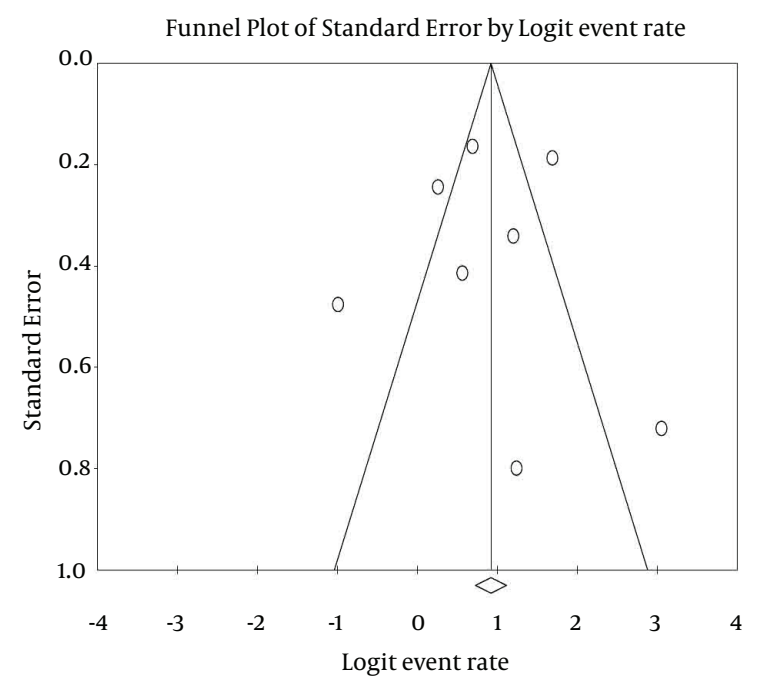

Figure 3. Funnel Plot Indicating the mean of aPCC in Bleeding Reduction

Figure 4. Mean of Efficacy of rFVIIa in Bleeding Reduction Based on Randomized Model

\begin{tabular}{|c|c|c|c|c|c|c|c|c|c|c|c|}
\hline \multirow[t]{2}{*}{ Model } & \multirow[t]{2}{*}{ Study name } & \multicolumn{5}{|c|}{ Statistics for each study } & \multicolumn{5}{|c|}{ Event rate and 95\% CI } \\
\hline & & Event rate & Lower limit & Upper & Z-Value & $\mathrm{p}$-Value & -1.00 & -0.50 & 0.00 & 0.50 & 1.00 \\
\hline \multicolumn{2}{|r|}{ Astermark, 2007 [FENOC) } & 0.756 & 0.616 & 0.857 & 3.365 & 0.001 & & & & \multirow{2}{*}{\multicolumn{2}{|c|}{+}} \\
\hline \multicolumn{2}{|r|}{ Dundar et al: Turkey, 2005} & 0.893 & 0.749 & 0.959 & 4.043 & 0.000 & & & & & \\
\hline \multicolumn{2}{|r|}{ Ozelo et al : Brazil, 2007} & 0.990 & 0.912 & 0.999 & 3.966 & 0.000 & & & & & \\
\hline \multicolumn{2}{|r|}{ You et al: South Korea, 2009} & 0.871 & 0.703 & 0.951 & 3.564 & 0.000 & & & & - & \\
\hline \multicolumn{2}{|r|}{ Kavaki at al, 2006 (1) } & 0.700 & 0.473 & 0.859 & 1.736 & 0.082 & & & & & \\
\hline \multicolumn{2}{|r|}{ Kavaki et al, 2006 (2) } & 0.650 & 0.426 & 0.823 & 1.320 & 0.187 & & & & & \\
\hline \multicolumn{2}{|r|}{ Mauser-bunschoten, 2002} & 0.800 & 0.671 & 0.887 & 4.037 & 0.000 & & & & $\rightarrow$ & \\
\hline \multicolumn{2}{|r|}{ Young: USA, 2008 [1] } & 0.375 & 0.169 & 0.689 & -0.925 & 0.355 & & & & - & \\
\hline \multicolumn{2}{|r|}{ Young: USA, 2008 [2] } & 0.545 & 0.374 & 0.706 & 0.508 & 0.611 & & & & 一 & \\
\hline \multicolumn{2}{|r|}{ Santagostino, Italy $<2006$} & 0.310 & 0.154 & 0.526 & -1.736 & 0.083 & & & & & \\
\hline \multicolumn{2}{|l|}{ Random } & 0.723 & 0.576 & 0.834 & 2.877 & 0.004 & & & & $\longrightarrow$ & \\
\hline
\end{tabular}

It was estimated 72.3\% with CI 95\% (lower limit 57.6\% and upper limit 83.4\%); Q value $=68.1, \mathrm{df}=9, \mathrm{P}$ value $<0.001, \mathrm{I}^{2}=80.5$ 
possible via at-home therapy, while, if it is associated with less severe bleeds, the specific sites of bleeds may affect the efficacy rates (35). In some cases, it is recommended to combine two agents or employ them sequentially for improving the effectiveness of treatment (35). However, the efficacy may be influenced by the specific bleeds sites (eg, elbow, knee, ankle, etc.). Sjamsoedin et al. (36) found that aPCC in treatment of elbow bleeds was more effective than in treatment of knee bleeds. This may therefore had affected the efficacy of therapies in this study.

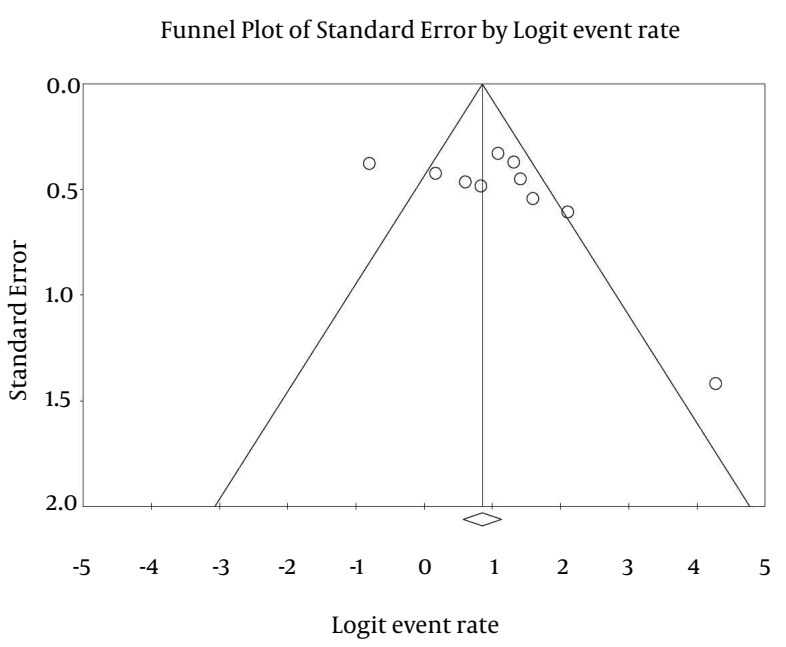

Figure 5. Funnel Plot Indicating the Mean of rFVIIa Efficacy in Bleeding Reduction

\section{Conclusions}

The results of this study indicated that although differences between the two products were very close, they had similar effects on joint bleeds. Further clinical studies should be performed on incorporating a standardized measurement for comparative efficacy of aPCC and rFVIIa.

\subsection{Strong Points of Our Study}

A strong point of our study was that although a few studies have been conducted in this field in Iran, metaanalysis is used to analyze the results of this study. In addition, most of the previous studies have investigated the efficacy of these products, but we tried to consider the type of effectiveness in reducing bleeding such as bleeding cessation, bleeding controlled and also reduction of the amount of bleedings.

\subsection{Weak Points of Our Study}

First, the authors searched the articles in Farsi database; but, due to lack of appropriate literature consistent with the search strategies, the search was restricted to English articles. Restrictions on access to full texts or lack of them were among the limitations of this study.

\section{Acknowledgements}

The authors would like to thank Mr. Saber Azami Aghdashlo and Mrs. Behnaz Habibpanah for cooperating during this study.

\section{Authors' Contributions}

All the authors contributed equally in editing this paper. They all read and approved the final manuscript.

\section{Financial Disclosure}

Dr Peyman Eshghi has acted as an invited speaker and consultant to NovoNordisk, Baxter, CSL, Aryogen and some other Pharmaceuticals Inc and he has not received any funding for research carried out in this work. The other authors had no interests in which might be perceived as posing a conflict or bias.

\section{References}

1. Knight C, Dano AM, Kennedy-Martin T. A systematic review of the cost-effectiveness of rFVIIa and APCC in the treatment of minor/ moderate bleeding episodes for haemophilia patients with inhibitors. Haemophilia. 2009;15(2):405-19.

2. Leissinger CA. Use of prothrombin complex concentrates and activated prothrombin complex concentrates as prophylactic therapy in haemophilia patients with inhibitors. Haemophilia. 1999;5 Suppl 3:25-32.

3. Eshghi P, Mahdavi-Mazdeh M, Karimi M, Aghighi M. Haemophilia in the developing countries: the Iranian experience. Arch Med Sci. 2010;6(1):83-9.

4. Mulder K, Llinas A. The target joint. Haemophilia. 2004;10 Suppl 4:152-6.

5. Konkle BA, Ebbesen LS, Erhardtsen E, Bianco RP, Lissitchkov T, Rusen L, et al. Randomized, prospective clinical trial of recombinant factor VIIa for secondary prophylaxis in hemophilia patients with inhibitors. J Thromb Haemost. 2007;5(9):1904-13.

6. Berntorp E. Differential response to bypassing agents complicates treatment in patients with haemophilia and inhibitors. Haemophilia. 2009;15(1):3-10.

7. Lloyd Jones M, Wight J, Paisley S, Knight C. Control of bleeding in patients with haemophilia A with inhibitors: a systematic review. Haemophilia. 2003;9(4):464-520.

8. Dimichele D, Negrier C. A retrospective postlicensure survey of FEIBA efficacy and safety. Haemophilia. 2006;12(4):352-62.

9. Young G, Cooper DL, Gut RZ, Htrs Investigators . Dosing and effectiveness of recombinant activated factor VII (rFVIIA) in congenital haemophilia with inhibitors by bleed type and location: the experience of the Haemophilia and Thrombosis Research Society (HTRS) Registry (2004-2008). Haemophilia. 2012;18(6):990-6.

10. Astermark J, Donfield SM, DiMichele DM, Gringeri A, Gilbert SA, Waters J, et al. A randomized comparison of bypassing agents in hemophilia complicated by an inhibitor: the FEIBA NovoSeven Comparative (FENOC) Study. Blood. 2007;109(2):546-51.

11. Knight C, Paisley S, Wight J, Jones ML. Economic modelling of different treatment strategies for haemophilia A with high-responding inhibitors. Haemophilia. 2003;9(4):521-40.

12. Odeyemi IAO, Guest JF. Modelling the economic impact of recombinant activated Factor VII and activated prothrombin-complex concentrate in the treatment of a mild to moderate bleed in adults with inhibitors to clotting Factors VIII and IX at a comprehensive care centre in the UK. J Med Econ. 2002;5(1-4):61-4.

13. Chung K, Berger A. , Edelsberg J, Neufeld E. Cost-effectiveness of FEIBA for the treatment of mildto-moderate bleeds in hemophil- 
ia patients with inhibitors. Haemophilia . 2004;10:29-33.

14. Putnam KG, Bohn RL, Ewenstein BM, Winkelmayer WC, Avorn J A cost minimization model for the treatment of minor bleeding episodes in patients with haemophilia A and high-titre inhibitors. Haemophilia. 2005;11(3):261-9.

15. Dundar S, Zulfikar B, Kavakli K, Gonen C, Zulfikar H, Yilmaz D. A cost evaluation of treatment alternatives for mild-to-moderate bleeding episodes in haemophilia patients with inhibitors in Turkey. J Med Econ. 2005;8:45-54.

16. Joshi AV, Stephens JM, Munro V, Mathew P, Botteman MF. Pharmacoeconomic analysis of recombinant factor VIIa versus APCC in the treatment of minor-to-moderate bleeds in hemophilia patients with inhibitors. Curr Med Res Opin. 2006;22(1):23-31.

17. Ozelo MC, Villaca PR, De Almeida JO, Bueno TM, De Miranda PA, Hart WM, et al. A cost evaluation of treatment alternatives for mild-to-moderate bleeding episodes in patients with haemophilia and inhibitors in Brazil. Haemophilia. 2007;13(5):462-9.

18. You CW, Lee SY, Park SK. Cost and effectiveness of treatments for mild-to-moderate bleeding episodes in haemophilia patients with inhibitors in Korea. Haemophilia. 2009;15(1):217-26.

19. Kavakli K, Makris M, Zulfikar B, Erhardtsen E, Abrams ZS, Kenet $\mathrm{G}$, et al. Home treatment of haemarthroses using a single dose regimen of recombinant activated factor VII in patients with haemophilia and inhibitors. A multi-centre, randomised, double-blind, cross-over trial. Thromb Haemost. 2006;95(4):600-5.

20. Santagostino E, Mancuso ME, Rocino A, Mancuso G, Scaraggi F, Mannucci PM. A prospective randomized trial of high and standard dosages of recombinant factor VIIa for treatment of hemarthroses in hemophiliacs with inhibitors. J Thromb Haemost. 2006;4(2):367-71.

21. Holme PA, Glomstein A, Gronhaug S, Tjonnfjord GE. Home treatment with bypassing products in inhibitor patients: a 7.5-year experience. Haemophilia. 2009;15(3):727-32.

22. Smejkal P, Brabec P, Matyskova M, Bulikova A, Slechtova M Kissova J, et al. FEIBA in treatment of acute bleeding episodes in patients with haemophilia A and factor VIII inhibitors: a retrospective survey in regional haemophilia centre. Haemophilia. 2009;15(3):743-51.

23. Mauser-Bunschoten EP, Koopman MM, Goede-Bolder AD, Leebeek FW, van der Meer J, van Marwijk Kooij GM, et al. Efficacy of recombinant factor VIIa administered by continuous infusion to haemophilia patients with inhibitors. Haemophilia. 2002;8(5):649-56.

24. Young G, Shafer FE, Rojas P, Seremetis S. Single 270 microg kg(1)-dose rFVIIa vs. standard 90 microg $\mathrm{kg}(-1)$-dose rFVIIa and APCC for home treatment of joint bleeds in haemophilia patients with inhibitors: a randomized comparison. Haemophilia. 2008;14(2):287-94.
25. Rasekh HR, Imani A, Karimi M, Golestani M. Cost-utility analysis of immune tolerance induction therapy versus on-demand treatment with recombinant factor VII for hemophilia A with high titer inhibitors in Iran. Clinicoecon Outcomes Res. 2011;3:207-12.

26. Zhou ZY, Hay JW. Efficacy of bypassing agents in patients with hemophilia and inhibitors: a systematic review and meta-analysis. Clin Ther. 2012;34(2):434-45.

27. Negrier C, Goudemand J, Sultan Y, Bertrand M, Rothschild C, Lauroua P. Multicenter retrospective study on the utilization of FEIBA in France in patients with factor VIII and factor IX inhibitors. French FEIBA Study Group. Factor Eight Bypassing Activity. Thromb Haemost. 1997;77(6):1113-9.

28. Parameswaran R, Shapiro AD, Gill JC, Kessler CM, Htrs Registry Investigators . Dose effect and efficacy of rFVIIa in the treatment of haemophilia patients with inhibitors: analysis from the Hemophilia and Thrombosis Research Society Registry. Haemophilia. 2005;11(2):100-6.

29. Key NS, Aledort LM, Beardsley D, Cooper HA, Davignon G, Ewen stein BM, et al. Home treatment of mild to moderate bleeding episodes using recombinant factor VIIa (Novoseven) in haemophiliacs with inhibitors. Thromb Haemost.1998;80(6):912-8.

30. Hilgartner MW, Knatterud GL. The use of factor eight inhibi tor by-passing activity (FEIBA immuno) product for treatment of bleeding episodes in hemophiliacs with inhibitors. Blood. 1983;61(1):36-40.

31. Quintana-Molina M, Martinez-Bahamonde F, Gonzalez-Garcia E Romero-Garrido J, Villar-Camacho A, Jimenez-Yuste V, et al. Surgery in haemophilic patients with inhibitor: 20 years of experience. Haemophilia. 2004;10 Suppl 2:30-40.

32. Knight C, Dano AM, Kennedy-Martin T. Systematic review of efficacy of rFVIIa and aPCC treatment for hemophilia patients with inhibitors. Adv Ther. 2009;26(1):68-88.

33. Treur MJ, McCracken F, Heeg B, Joshi AV, Botteman MF, De Charro F, et al. Efficacy of recombinant activated factor VII vs. activated prothrombin complex concentrate for patients suffering from haemophilia complicated with inhibitors: a Bayesian meta-regression. Haemophilia. 2009;15(2):420-36.

34. Egger M, Smith GD, Altman D. Systematic Reviews in HealthCare: Meta-Analysis in Context.Boston: BMJ Books; 2001.

35. Di Minno MN, Minno G, Capua M, Cerbone AM, Coppola A. Cost of care of haemophilia with inhibitors. Haemophilia. 2010; 16(1):e190-201.

36. Sjamsoedin LJ, Heijnen L, Mauser-Bunschoten EP, van Geijlswijk JL, van Houwelingen $\mathrm{H}$, van Asten P, et al. The effect of activated prothrombin-complex concentrate (FEIBA) on joint and muscle bleeding in patients with hemophilia $A$ and antibodies to factor VIII. A double-blind clinical trial. N Engl J Med.1981;305(13):717-21. 